\title{
Interdenominational Cooperation in Religious New Media Projects: the Case of the Christian Media Center
}

\author{
Michele Martini $^{1,2}$ (D)
}

Received: 26 January 2020 / Accepted: 11 March 2020 / Published online: 16 April 2020

(C) The Author(s) 2020

\begin{abstract}
In the last decade, macro religious institutions have undergone a process of digitalisation that enabled them to incorporate Internet Communication Technologies in their organisational infrastructure. Stemming from digital religion scholarship, the research presented in this paper relate to a study of the philosophy and functioning of an innovative Catholic media enterprise called Christian Media Center (CMC). Based in Israel and the Occupied Palestinian Territories, the CMC was established through the cooperation between the long-standing Franciscan Order and the technology-savvy Brazilian community of Canção Nova. Accordingly, this paper asks: which forms of interdenominational negotiation are involved in the functioning of the CMC? Drawing on interviews conducted during three years, this research will outline the process of internal negotiation required by the development of this Catholic new media project and propose possible directions for future research.
\end{abstract}

Keywords Digital religion · Canção Nova · New media $\cdot$ Catholicism · Holy Land · Social networks

\section{Introduction}

In the last two decades, the capillary diffusion of web 2.0 had a profound impact on those forms of governance and leadership that characterised the socio-political landscape of the twentieth century. Nevertheless, well-established institutions such as national states and religious organisations are today far from perceiving the Internet as a threat to their existence. While not natives of the digital world, these institutions have in many cases undergone a process of digitalisation that enabled them to integrate

Michele Martini

martinimichele86@yahoo.it

1 University of Cambridge, Faculty of Education, Cambridge, United Kingdom

2 Department of Religious Studies, Pontifical Catholic University of São Paulo, São Paulo, Brazil 
Internet Communication Technologies (hereafter ICTs) in their activities. The adoption of new media by devotional groups of different faiths has attracted scholarly interest. Under the umbrella term of "digital religion", researchers from different disciplinary backgrounds have started investigating the ways religious communities develop their outreach strategies on the Internet and how, in turn, the perceived necessity of competing in today's digital market affects their organisational structure.

Stemming from digital religion scholarship, the research presented in this paper relates to a three-year study of the philosophy and functioning of an innovative Catholic media enterprise called Christian Media Center (hereafter CMC). Based in Israel and the Occupied Palestinian Territories, the main objective of the CMC is to produce and disseminate on a global scale devotional media products focused on the Holy Land. ${ }^{1}$ This religious media initiative results from the cooperation between the well-established Franciscan Order and the emerging community of Canção Nova, a Brazilian Catholic charismatic community whose primary objective is global evangelisation with ICTs. Accordingly, this paper asks: which forms of interdenominational negotiation are involved in the development and functioning of the CMC?

Canção Nova's collaboration with the Franciscan Order offers the opportunity to observe how the rise of technology-savvy religious actors is affecting power balances within the Catholic world. The study covered several different areas of interest, which included the mapping of the CMC working structure and the analysis of the produced media. As part of this larger inquiry, the present research will illustrate how the establishment of this innovative media project required the interaction between three religious groups that differ in historical, cultural and doctrinal backgrounds: the Franciscan Order, Canção Nova and Syriac Maronite Church of Antioch. Drawing on interviews conducted during three years of research, this paper will outline the process of interdenominational negotiation required by the development of the $\mathrm{CMC}$ project and propose possible directions for future research.

\section{Going Digital: Managing Religious Communities on the Internet}

The capillary diffusion of smart technologies has pushed religious communities to regulate and theologically legitimise various forms of coexistence with the digital world (Golan and Stadler 2016; Grieve 2010; Hoover and Clark 2002). On the one hand, bounded communities and conservative leaders still regard digital media as gateways to sinful information and religious transgression (Golan and Mishol-Shauli 2018; Hutchings 2011; Lövheim 2017). On the other hand, new media are today welcomed by many denominations as ways to enhance religious learning, facilitate the expansion of the community and strengthen existing communal bonds (Blondheim and Katz 2016; Campbell 2010; Grieve and Veidlinger 2014). From this perspective, the emergence of online devotional media is consistent with an already existing trend in both well-established religious organisations and emerging cults. Indeed, before the advent

\footnotetext{
${ }^{1}$ Given the complex geopolitical situation of the region, the emic term "Holy Land" will be employed in this paper to identify a geographical area that includes all major Catholic sanctuaries related to the biblical narrative. This area comprises Israel, the Occupied Palestinian Territories, Jordan, Lebanon, Syria, Cyprus, Rhodes and part of the Sinai Peninsula.
} 
of the digital era, outreach campaigns of religious groups efficiently employed radio programming (Lehmann and Siebzehner 2006), cassette distribution (Echchaibi 2011; Hirschkind 2006), newspapers (Nardella 2012) and televangelism (Bruce and Pray 2019).

As social networks require only minimal investment in order to disseminate contents on a potentially global level (Martini 2018a), these platforms initially attracted small-scale religious organisations with limited budget and often amateurish technical capabilities (Martini 2018b; Piraino 2016; Radde-Antweiler 2006). However, with the evolution and expansion of the digital landscape, new media entrepreneurship gained importance also in major religious institutions. While in line with an existing tradition of devotional media production, the introduction of social networks and smart technologies represents a major change in the ways institutions construct the collective identity of believers. Accordingly, leading scholars endeavoured to design new research approaches, such as "Religious-Social Shaping of Digital Technology" (Campbell 2017), and develop theoretical concepts for the analysis of digital religion, such as "cultured technology" (Barzilai-Nahon and Barzilai 2005) and "third spaces" (Hoover and Echchaibi 2014).

The research focused on the institutional and theological transformations required by the adaptation of devotional and communal practices to the digital market. This included the management of the community (Miller 2015; Jacobsen and Myrvold 2019), the role of religious webmasters within traditional hierarchies (Cheong et al. 2011; Golan and Martini 2019a) and the performance of religious rituals through smart technologies (Evolvi 2018; Grieve and Veidlinger 2014). In this area, particular attention has been devoted to investigating the impact of new media on religious leadership, including transformations in communal structures, ideologies and scriptural exegesis (Campbell 2007). Turner (2007), for example, discusses how online flows of knowledge might fundamentally disrupt religious authority, therefore requiring the development of post-Weberian categories. Similarly, Golan and Martini (2019b) show how social networks are strategically employed by well-established religious leaders to hybridise their public image and fluidly shift between different forms of legitimacy.

Within this stream of research, the present research intend to sketch the internal renegotiation processes that multi-layered religious organisations, such as the Catholic Church, undergo in order to integrate new media outlets in their infrastructure. Indeed, while often reaffirming the legitimacy of top-level leaders, these transformations affect the inner functioning of religious institutions by allowing the covert emergence of new forms of expertise, task-related values and secondary authorities.

\section{Ethnography of Religious Media Production: Franciscan-Charismatic Cooperation in the Holy Land}

The fieldwork was conducted from 2014 to 2017 and investigated the organisation, the activities and the media production of the Christian Media Center (CMC). The CMC originates from the cooperation between the Franciscan Custody of the Holy Land (hereafter, the Custody), the Syriac Maronite Church of Antioch and the Brazilian charismatic community Canção Nova. The CMC headquarters are located in Jerusalem, at the Terra Sancta College, which hosts the studios, the editorial board and the editing offices. The project is financially 
supported by the Custody and directed by the Canção Nova community, while the staff includes Italian journalists, Franciscan monks, Palestinian videomakers and Brazilian Canção Nova members.

The core mission of the CMC is to document the life of the Catholic community in the Holy Land, from religious rituals to everyday activities, and disseminate these media products through both television broadcasts and online outlets. At present, the CMC addresses global believers with (a) highdefinition online videos (religious events, sermons, documentaries, etc.) in five languages (English, French, Italian, Arabic, Portuguese); (b) live coverage of key Catholic celebrations (online streaming/satellite) and (c) weekly newscasts differentiated between the international and the Arab-speaking public. Pilot projects include 24/7 live-streaming from the most important holy sites and (d) 360 Virtual Reality videos of main catholic celebrations. Web traffic data form Google Analytics show that in 2015 the new-born CMC website was already receiving more than 45,000 pageviews per month, with a $37.9 \%$ rate of returning visitors over a period of 9 months. However, it is not easy to estimate the actual impact of the CMC's activity, as this organisation focuses more on production than on distribution. Accordingly, media products are meant to be circulated mostly by third parties. This includes not only social media platforms, but also television and radio broadcasts. For example, at present, the CMC has an established cooperation with 38 TV partners around the world and several Catholic social network pages, including the Canção Nova Facebook page that counts more than two million followers (March 2020).

In the course of the ethnography, researchers followed the work of the CMC team during the celebrations of the liturgical year. This included Christmas celebrations in Bethlehem, Good Friday vigils at the Gethsemane Garden and Easter ceremonies at the Holy Sepulchre. In all these cases, researchers documented the employed technologies, the division of labour and the interaction with the local clergy. The media production process was then followed during the editing and dubbing stages, until the final upload to the website. The produced media were subsequently collected and coded. The coding scheme was designed to highlight the online construction of the sacred through audiovisual means.

During the first two years of observation, a series of semi-structured interviews was conducted with the different groups composing the working staff, the general director of the CMC and the representatives of the Franciscan Order. Key informants were selected using a purposive sampling strategy augmented with snowball sampling. These discussions focused on the functioning of the CMC, the role of new media in the evangelising mission and the collaboration between long-standing and emerging religious groups. The interview protocol included questions such as: Can an online content convey holiness? Do different religious groups struggle to assume a leading role on the Internet? What are the advantages/disadvantages of working with people from other denominations?

Interviews were coded to investigate three main themes: the webmasters' objectives, the webmasters' perception of new media and the interdenominational negotiation between the different groups taking part in the project. Findings presented in the 
following section refer to the third theme and portray the different views which emerged from these discussions.

\section{Mapping the cooperation between three religious groups: Franciscan Order, Canção Nova and the Maronite Church}

\section{The Franciscan Custody of the Holy Land}

The Franciscan Custody of the Holy Land (Custodia Terrce Sanctoe) is a branch of the Franciscan Order that is in charge of guarding the holy places on behalf of the Catholic Church. Saint Francis of Assisi established both the Custody and the Franciscan Province of the Holy Land in 1217. Since then, the Franciscan Order has maintained a constant presence in the region, as well as the right to access all major Christian holy sites $^{2}$. The rationale behind the creation of the CMC is explained by Mons. Pierbattista Pizzaballa (Jerusalem, 2015), former Custos of the Holy Land:

We have always paid attention to the media. To use them, as we say, to communicate the message of the Holy Land. For the Internet... we might have been a bit slow. Because this form of communication is quite different from the press. It is more complex, more expensive and requires a level of professionalism that one does not acquire with simple obedience: go and do it. You need to know how to do it. For this reason, we needed to cooperate. The Franciscan monks did not have the competence, we needed a total change. In the past, we had preachers in the squares, today there are virtual squares and we have to be there.

In this excerpt, Mons. Pizzaballa exposes his perception of a gap in the ways the Order has engaged with the digital world. The emergence of what he defines as "virtual squares" made clear to him the limits of traditional monastic education and triggered the search for possible solutions through external cooperation. A similar concern is expressed in the following section:

I proposed it to the Discretorium [the Council of the Custody], but everybody was aware of this: we needed a multimedia centre. We had a space, ok, but.. how do we make it? We buy the machines but... which machines? How do we use them? We needed help. So, we heard about this Canção Nova. We needed people who have this [use of media] in their charisma and could help us to develop the project. Besides, they are consecrated and this has a great value also on an economic level, because in the long run paying thirty salaries is not the same as paying fifteen. They were searching a way to connect to the Holy Land, so we got in touch.

The process that brought the Custody to develop a cooperation with the media-savvy community of Canção Nova is here presented in more detail. Mons. Pizzaballa initially depicts how the Discretorium reacted to the idea of establishing a multimedia center: 
with a sense of urgency and, at the same time, of helplessness. From this perspective, the fruitful encounter with Canção Nova is presented as an interesting mixture of religious values, technical skills and economic strategy. The fact of being consecrated, i.e. to include media work in their mission as a religious community, made the Canção Nova a suitable partner not only in terms of ideology, but also because they could guarantee better stability and continuity to the project. However, differences in religious praxis and cultural background were highlighted in the last part of the interview:

We have different sensibilities. Brazil, Latin America and Middle East have very different ways of communicating. On the idea of evangelizing, we agree. How to evangelize... clearly, the content is Jesus Christ, but on how to communicate this message, we are not necessarily on the same page. So, I believe we both need to make an effort to cooperate. We might not be so charismatic in our spirit, but they could learn to understand a bit of latinorum ${ }^{2}$ !

In this conclusive passage, Mons. Pizzaballa explicitly highlights the existence of a tension between the Custody and Canção Nova. While the two groups have a common objective, i.e. the evangelisation, they diverge on communication strategies. It is interesting to note how, in this small excerpt, Mons. Pizzaballa shifts from cultural to doctrinal motivations. At the beginning, he stresses how projects of global evangelisation need to adapt their religious message to different sensibilities and forms of communication. However, at the end he ironically yet strongly reaffirms the value of the traditional way of circulating theological meanings within the Catholic Church, i.e. the use of Latin, in the face of much more popular communicative strategies developed by charismatic groups.

\section{Canção Nova in the Holy Land}

Canção Nova is a Brazilian Catholic Charismatic community whose primary mission is evangelisation with new media. Founded in 1978 by Mons. Jonas Abib as a fulfilment of the Apostolic Exhortation Evangelii Nuntiandi, Canção Nova's doctrine combines religious praxis and professional media activity (Carranza and Mariz 2013). Paolo, ${ }^{3}$ member of Canção Nova and director of the $\mathrm{CMC}$, recounts the beginning for their cooperation with the Custody:

The community got established in the Holy Land more than 10 years ago. Shortly after came the work with the Franciscans, who wanted to open a centre for communication. Because when we talk of the Holy Land, what do people think about? War, bombs, death, terrorism and all that. We want to divulgate good news from here: the pilgrimages, the liturgy in the holy places, the life of the local

\footnotetext{
2 The term "latinorum" is today employed in Italian to mock the unjustified use of obscure jargon. It first appeared in the novel I Promessi Sposi (Manzoni 2014), where was used by an uneducated man to accuse a priest of speaking Latin in order to confuse him. In this case, Mons. Pizzaballa is ironically stressing the fact that the importance of the traditional knowledge of the Catholic Church should not be downplayed.

3 To protect the privacy of informants, CMC workers' names have been substituted with pseudonyms.
} 
Christians. Because faith is also lived here, in a very present way. So these good news have to be spread. Our charisma, as Canção Nova, is to divulgate, it is to evangelize a living and lived Jesus. So nothing better, right? We united both realities, both desires: from the Custody to divulgate and the Canção Nova community to make it happen. We put together the consecrated people that are formed in media communication and the Custody, which gave the structure. (Jerusalem 2016).

In this description, Paolo stresses how cooperation with the Custody is not only based on a fruitful exchange of qualified media workforce and technical infrastructure, but also on a common goal: to reclaim the primacy of the spiritual value of the Holy Land over its mainstream media representation. Accordingly, Paolo presents the work of the $\mathrm{CMC}$ as a reaction against the negative image constructed by the secular media industry. However, beside this reactionary dimension, the project is also portrayed as having an independent spiritual objective. Juliana, a Canção Nova webmaster, describes it in these terms:

Our mission will always be to evangelize and save souls through media tools. Take the living Jesus through TV, radio, internet, social media. Because this was the tool God gave us. So we, with what God gave us, these talents for media, help the Custody and the Franciscans to take all this richness that exists here in the Holy Land to the world. So we transform it in videos, in news, in documentaries, to take it to people who will not ever be able to be here, to touch this place, so sacred, so beautiful, where our God and our Lord passed. So this is a great mission for us, to transform all this richness in videos, in documentaries: record all that and take it to Brazil, Portugal, all the nations. Because our way, the internet, goes everywhere. (Jerusalem, 2015).

In this excerpt, Juliana highlights an important trait underpinning Canção Nova’s religious mission: the perceived spiritual agency of media. This form of agency is justified, in line with the doctrinal position expressed by several papal encyclicals, by the redefinition of media as tools received directly from God. Through a process of transformation into media products, the "richness of the Holy Land" transcends its geographical dimension and can be circulated through the Internet on a global level. In this respect, Ana, a Canção Nova journalist, reaffirms the importance of the local context:

The work of the Custody is very beautiful, and if it was not for them here in the Holy Land, probably we would not be here either. So the Canção Nova today cooperates to spread this knowledge of what the Holy Land is. Because the Franciscans give us this space, so we can work, enter the sanctuaries, record there... And show to the world the beauty of the Holy Land. Everything happened here, in the Holy Land, all started here. So for us this is beautiful, to be able of having this partnership to show everything they do here, all that was done in these 800 years of Franciscan presence. We have been here for 10 years only... it's nothing compared to 800 years. (Jerusalem 2016). 
To conclude, Ana stresses the strategic importance of the cooperation with the Custody. Firstly, they provided them with the necessary financial support and infrastructure on the ground. Secondly, for historical and legal reasons, the Custody was able to guarantee them access to all main sanctuaries. It should be noted that, given the complex body of regulations governing the religious organisation of the region (e.g. Status Quo), this level of access is rarely obtainable by secular media enterprises. Thirdly, and perhaps implicitly, Ana expresses admiration for the long history of the Franciscan Order and comparatively links it to that of the young Canção Nova.

\section{The Maronite Church and the Local Catholic Community}

In Israel, Christian communities represent a small religious minority that makes up approximately $2 \%$ of the population (Israel Central Bureau of Statistics 2018). Among these groups, the vast majority adhere to the Melkite Catholic Church and the Greek Orthodox Church, while only a minority (about 7000 people) belong to the Syriac Maronite Church. Nevertheless, this small yet ancient Eastern Catholic Church has played a central role in making possible the connection between the Custody and the Canção Nova, as recounted by deacon Youssef:

I am the deacon Youssef, from Acre, Galilee. I work in Jerusalem as General Director of the $\mathrm{CMC}$, which is an organization created at the behest of the Episcopal Conference of the Holy Land and then realized by the Custody. I am a Maronite deacon and also the Chancellor of the Maronite Patriarchate, I met Canção Nova 25 years ago and I brought them here in Israel. They are integrated in the Maronite Church, for what concerns their presence in the Holy Land as a Christian community. I am their administrator here and also an ex-student of the Franciscans. So, I know the Custody, I know Canção Nova and I am form here, from the [region of] Galilee.

Youssef introduces himself as an official representative of the Maronite Church in Israel and, perhaps more importantly, as a linking figure between the different actors that cooperate in the management of the CMC. Interestingly enough, Youssef relies on the concept of indigeneity to construct his role: as a native of Galilee, he presents himself as the legitimate point of connection between two non-native communities and the Holy Land. However, as he explains, the connection between the Maronite Church and Canção Nova dates back to the foundation of the Brazilian community:

In 2006 [...] I already had connections with the Brazilians of Canção Nova and I knew that they were born to work with media. Canção Nova was founded by Father Jonas Abib, who is a Lebanese Maronite, to evangelize. Canção Nova has grown a lot and I have been following its growth because I have been their friend since the $80 \mathrm{~s}$. I was often in Brazil with them. So, moving between here and there, I say to the Custos: let us ask this community which has experience with the TV, the radio and everything. So, three of them came and we started working on the CMC. The centre did not exist before: zero.

In this excerpt, Youssef highlights the importance of the already existing link between the Maronite Church of the Middle East and its diasporic counterpart in Brazil. This 
connection is presented as being rooted in the very core of Canção Nova: its founder, Mons. Jonas Abib, is a Brazilian citizen of Lebanese origin and Corepiscopo of the Maronite Church. From a doctrinal perspective, then, the cooperation between the media-savvy charismatic community of Canção Nova and the Custody is presented by Youssef as mediated by a third religious actor whose history has been deeply affected by the several waves of Lebanese migration to Latin America (Tabar 2010).

\section{Discussion and Conclusion}

This research aimed at providing an example of how the establishment of religious media enterprises elicits unprecedented forms of cooperation between different Catholic organisations on a global level, by asking: which forms of interdenominational negotiation are involved in the development and functioning of the CMC? Findings suggest that, within macro religious institutions, the establishment of religious new media projects generates a double movement. On the one hand, high-ranked traditional groups actively pursue the cooperation with technology-savvy organisations. On the other hand, emerging religious communities that incorporate new media work in their mission aim at legitimising and expanding their activities through cooperation with well-established orders.

In the case under scrutiny, the Franciscan Custody firstly perceived the creation of the $\mathrm{CMC}$ as a need. Mons. Pizzaballa describes this need as a feeling of urgency that was experienced, perhaps unconsciously, by the members of the Discretorium. The rapid emergence of new media has partially compromised the effectiveness of traditional forms of evangelisation while de facto excluding the monks from the "digital squares", as he calls them. This feeling of exclusion and loss of control seems to be at the core of the Custody's decision to cooperate with an external group. The Internet is perceived by the Franciscan Custody as an environment that cannot be dealt with by relying on the order's long-standing rules, such as that of obedience, but requires the mastering of a completely new body of knowledge and, perhaps, the emergence of a new religious subjectivity. Mons. Pizzaballa stresses this fact by recounting the state of impasse that followed the decision of creating a multimedia centre and culminated in the establishment of a cooperation with the Canção Nova community.

Compared to the Franciscan Order, the Brazilian community of Canção Nova is a very young religious organisation. Nonetheless, members of Canção Nova stress the potential of their expertise to manage and expand "the beauty of the Holy Land", perceived as a primary source of sacredness. The acquisition of a higher level of proximity to the sacred, made possible by the cooperation with the Franciscan Custody, represents a useful lens through which to discuss the transforming position of the Canção Nova within the Catholic hierarchy. As emphasised by the interviewees, their intense engagement with ICTs is based on the conviction that new media can expand the spiritual influence of sanctuaries beyond their geographical limits. While the theological value of this position might be a matter of disagreement between Canção Nova and the Custody, both sides agree that a strategic mediatisation of the Holy Land was required by the evolving social landscape. Accordingly, high-level media expertise represented a key factor in persuading the Custody to guarantee to Canção Nova privileged access to religious sites of primary importance (e.g. the Holy Sepulchre or the Nativity Church). The persistence of this agreement relies on a permanent negotiation between the two communities, as well as a clear hierarchical relationship. 
Nevertheless, the acquisition of a sort of monopoly over the media representation of the Holy Land and the development of a stable partnership with the Franciscan Order represented for Canção Nova is a major step toward its integration in the Catholic hierarchy.

The role played by the local Maronite Church in connecting the two communities highlights an important, yet often neglected, dynamic. Indeed, while global in their aspirations, these online projects operate in local settings that are highly impacted by the emergence of media enterprises. The investigation of this aspect is beyond the aims of this paper, but the presented findings indicate possible directions for future inquiry. In the case under scrutiny, we observed the overlapping of several transnational movements that occurred in different historical moments, such as the arrival of the Franciscans in the Holy Land in 1217 and the various waves of Lebanese migration to Latin America during the twentieth century. This suggests that, once again, religious media projects should not be studied as a novelty arising from the popularisation of the Internet, but rather as multifaceted phenomena emerging from transnational transformations that precede the advent of the Internet by several centuries. This, in turn, invokes a much deeper discussion concerning the evolution of the idea of globality within organised religion and its impact on the development of local religious communities.

To conclude, the present research suggests that the popularisation of new media on a global scale is affecting the Catholic Church on several levels, including doctrinal and infrastructural changes. Findings shed light on how, in this case, the perceived necessity to engage in online evangelisation brought a traditional monastic order to establish a close cooperation with new religious subjectivities that incorporate media work in their devotional praxis. Accordingly, this study invites further research on the emergence of technology-savvy religious actors and their progressive inclusion in the traditional hierarchy of macro religious institutions.

Funding This project has received funding from the European Union's Horizon 2020 research and innovation programme under the Marie Skłodowska-Curie grant agreement No 837727.

\section{Compliance with ethical standards}

Conflict of interest The authors declare that they have no conflict of interest.

Open Access This article is licensed under a Creative Commons Attribution 4.0 International License, which permits use, sharing, adaptation, distribution and reproduction in any medium or format, as long as you give appropriate credit to the original author(s) and the source, provide a link to the Creative Commons licence, and indicate if changes were made. The images or other third party material in this article are included in the article's Creative Commons licence, unless indicated otherwise in a credit line to the material. If material is not included in the article's Creative Commons licence and your intended use is not permitted by statutory regulation or exceeds the permitted use, you will need to obtain permission directly from the copyright holder. To view a copy of this licence, visit http://creativecommons.org/licenses/by/4.0/.

\section{References}

Barzilai-nahon K, Barzilai G (2005) Cultured technology: the Internet and religious fundamentalism. Inf Soc 21(1):25-40

Blondheim M, Katz E (2016) Religion, communications, and Judaism: the case of digital Chabad. Media Cult Soc 38.1:89-95

Bruce, S, Pray TV 2019 televangelism in America. Routledge 
Campbell H (2007) Who's got the power? Religious authority and the Internet. J Comput-Mediat Commun 12(3):1043-1062

Campbell H (2010) When religion meets new media. Routledge

Campbell HA (2017) Surveying theoretical approaches within digital religion studies. New Media Soc 1:1524

Carranza B, Mariz C. (2013) Catholicism for export: the case of Canção Nova. In: The diaspora of Brazilian religions. Brill, p. 137-162

Cheong PH, Shirlena H, Poon Jessie PH (2011) Religious communication and epistemic authority of leaders in wired faith organizations. J Commun 61(5):938-958

Echchaibi N (2011) From audio tapes to video blogs: the delocalisation of authority in Islam. Nations Natl 17(1):25-44

Evolvi G (2018) Blogging my religion: secular, Muslim, and Catholic media spaces in Europe. Routledge

Golan O, Martini M (2019a) Religious live-streaming: constructing the authentic in real time. Inf Commun Soc 3:437-454

Golan O, Martini M. (2019b) The making of contemporary papacy: manufactured charisma and Instagram. Inform Commun Soc, 1-18

Golan O, Mishol-Shauli N (2018) Fundamentalist web journalism: walking a fine line between religious ultraorthodoxy and the new media ethos. Eur J Commun 33(3):304-320

Golan O, Stadler N (2016) Building the sacred community online: the dual use of the Internet by Chabad. Media Cult Soc 38.1:71-88

Grieve G. (2010) Virtually embodying the field: Silent online buddhist meditation, immersion, and the cardean ethnographic method. Online-Heidelberg Journal of Religions on the Internet: Vol. 04.1 Special Issue on Aesthetics and the Dimensions of the Senses

Grieve GP, Veidlinger D (2014) (ed.). Buddhism, the internet, and digital media: The pixel in the lotus. Routledge

Hirschkind C. (2006) The ethical soundscape: cassette sermons and Islamic counterpublics. Columbia University Press

Hoover SM, Clark LS. (2002) Practicing religion in the age of the media: Explorations in media, religion, and culture. Columbia University Press

Hoover S, Echchaibi N. (2014) Media theory and the "third spaces of digital religion.". Finding religion in the media: Work in progress on the third spaces of digital religion

Hutchings T (2011) Contemporary religious community and the online church. Inf Commun Soc 14(8):11181135

Israel Central Bureau of Statistics (2018) Society in Israel, Report No. 10: religion and self-definition of level of religiosity. Central Bureau of Statistics, Jerusalem

Jacobsen KA, Myrvold K. (2019) Religion and Technology in India: Spaces, Practices and Authorities. Routledge

Lehmann D, Siebzehner B. (2006) Holy pirates: media, ethnicity, and religious renewal in Israel. Religion, media, and the public sphere 91-111

Lövheim M. (2017) Media and religion: bridging 'incompatible agendas'. In: Foundations and futures in the sociology of religion. Routledge. p. 39-52

Manzoni A (2014) I promessi sposi. Edulingua, Recanati

Martini M (2018a) On the user's side: YouTube and distant witnessing in the age of technology-enhanced mediability. Convergence 24(1):33-49

Martini M (2018b) Online distant witnessing and live-streaming activism: emerging differences in the activation of networked publics. New Media Soc 20(11):4035-4055

Miller AR. (2015) Negotiating religious identity and mass media: examining the relationship among lived religion, mass media, and narrative identity. Temple University

Nardella C (2012) Religious symbols in Italian advertising: symbolic appropriation and the management of consent. J Contemp Relig 27(2):217-240

Piraino F (2016) Between real and virtual communities: Sufism in Western societies and the Naqshbandi Haqqani case. Social Compass 63(1):93-108

Radde-Antweiler K. (2006) Rituals online: transferring and designing rituals. Online-Heidelberg J Religions Internet 2

Tabar P. (2010) Lebanon: a country of emigration and immigration. Instit Migration Stud, 7

Turner BS (2007) Religious authority and the new media. Theory Culture Soc 24.2:117-134

Publisher's Note Springer Nature remains neutral with regard to jurisdictional claims in published maps and institutional affiliations. 